Reprod. Nutr. Dévelop., 1984, 24 (5A), 507-513.

\title{
Sex play and behavioural sexualization in the pig.
}

Maryse BERRY, J.-P. SIGNORET

Laboratoire de Comportement Animal, I.N.R.A., Nouzilly, 37380 Monnaie, France.

Summary. The patterns of adult copulatory behaviour can be observed in piglets. This sex play is more frequent in young boars than in young sows and reaches a peak during the second neonatal month.

The castration of young boars within $5 \mathrm{~min}$ after birth ( 7 animals) eliminated the intense sex play of the second month. Gonadectomy at 30 days ( 3 animals) did not change mounting frequency during the second month, but reduced it during the third month. Castration at 60 days ( 7 animals) did not influence later mounting frequency.

As adults ( 6 to 8 months of age), boars castrated at birth or at 30 or 60 days displayed typical female immobilization after an injection of $1 \mathrm{mg}$ of oestradiol benzoate intramuscularly. In those castrated at 120 or 150 days of age (4 animals in each case) the female reaction was observed in only $35 \%$ of cases. No female response was observed in boars castrated at 180 days ( 3 animals). Sexualization of the nervous mechanisms of sexual behaviour in boars develops slowly and progressively during the prepubertal period and is independent of the evolution of sex play.

\section{Introduction.}

Male rats exhibit sexualization of the nervous mechanisms of copulatory behaviour. The motor responses and characteristic posture of female sexual receptivity, $i$. e. lordosis, can only be induced with difficulty in a male rat castrated when adult and receiving an adapted hormone treatment.

On the other hand, ovariectomized female rats present a characteristic receptive reaction after sequential injections of oestrogens and progesterone. Although not as responsive as male rats, female rats can display male-type activities after repeated injections of androgens. The sexualization of male nervous mechanisms seems to be due to the action of androgens secreted during development. Neonatal castration prevents this sexualization, while testosterone treatment at that time makes the castrate unable to display female sex responses (Whalen and Edwards, 1967).

These results cannot be extended to all species since Ford and Schanbacher (1977) observed that when boars were castrated at two weeks of age they showed characteristic female postural responses (receptive sows present a typical 
immobilization reaction when stimulated in the dorsal region). After sows are ovariectomized, the injection of oestrogens induces all the aspects of normal sexual receptivity (Signoret, 1972 ; Ford and Schanbacher, 1977 ; Ford, 1982). Ford and Schanbacher (1977) and Ford (1982) observed this reaction in boars castrated at or before 120 days of age. The late and progressive sexualization of the nervous mechanisms of sexual behaviour in this species would be related with the progressive increase of steroid secretion characterizing the prepubertal period (Meusy-Dessolle, 1976 ; Ford, 1983). Therefore, there is a long period during wich sexualization can be studied in pigs.

As in many other species, all the patterns of adult boar sexual behaviour can be observed in young animals long before puberty (ritualized approach and mounting, for example). The pattern of changes in this sex play in lambs is very characteristic during the first neonatal weeks (Orgeur, 1982). We thought that this play might be related with endocrine events and that by studying it we would gain some insight into the evolution of the sexualization process.

The aim of the present work was twofold :

1) to show the evolution of sex play in piglets and the effect of castration at different ages ;

2) to test the hypothesis of a relationship between this process and the sexualization of the nervous processes involved in adult sexual behaviour.

\section{Material and methods.}

A. Ontogenesis and sex play in piglets. - We studied 28 young boars and 30 young sows of the Large-White breed from six litters, identified from the first neonatal day by numbered tags on each ear. The boars were castrated at the following ages : within 5 min after birth ( 7 animals), at 30 days (3), 60 days (7), 120 days (4), 150 days (4) and 180 days (3). They were weaned at 5 weeks of age.

From birth to the pubertal period (5 months), each litter or mixed group was observed for two 30-min periods each week. Changes in the behavioural sequences were recorded directly during observation using a Datamyte data recorder permitting identification of the animals and of the type and length of each behavioural element. The data of two successive weeks were pooled. We only analysed mounting which is the single non ambiguous element specific to the sexual repertory.

B. Induction of female-type behaviour in boars. - When 6 months old, each castrated boar received a single injection i. $\mathrm{m}$. of oestradiol benzoate $(1 \mathrm{mg} / \mathrm{boar}$ ) in the neck. This treatment is reported to induce oestrous behaviour lasting for an average of $72 \mathrm{~h}$ with a latency of 3 days in sows of the same age (Signoret, 1972). Four days before and 4 days after injection, 5-min tests were carried out daily by putting each castrated boar with a stimulus-adult boar and testing the immobilization reaction of the experimental animal by trying to sit on its back. Two test series were carried out at a 3-week interval equal to the length of the sow oestrous cycle.

The statistical significance of the observed differences was evaluated according to the methods of variance analysis, Student's t-test and $\chi^{2}$. 


\section{Results.}

\section{A. Piglet sex play}

1) Intact animals. - A sexual-type play appeared in piglets during the first neonatal months. It was characterized by the motor pattern of behaviour of an adult boar (sniffing the genital region and mounting accompanied by pelvic movements) and by a typical manifestation of female behaviour, such as willingness to be mounted. Thus, male and female sex-play activities coexisted in piglets of both sexes.

The mean mounting frequencies as a function of piglet age were significantly different $(P<0.025$; fig. 1$)$, reaching a maximum during the second month. These reactions were observed in animals of both sexes, but their frequency was higher in boars than in sows $(P<0.01)$.

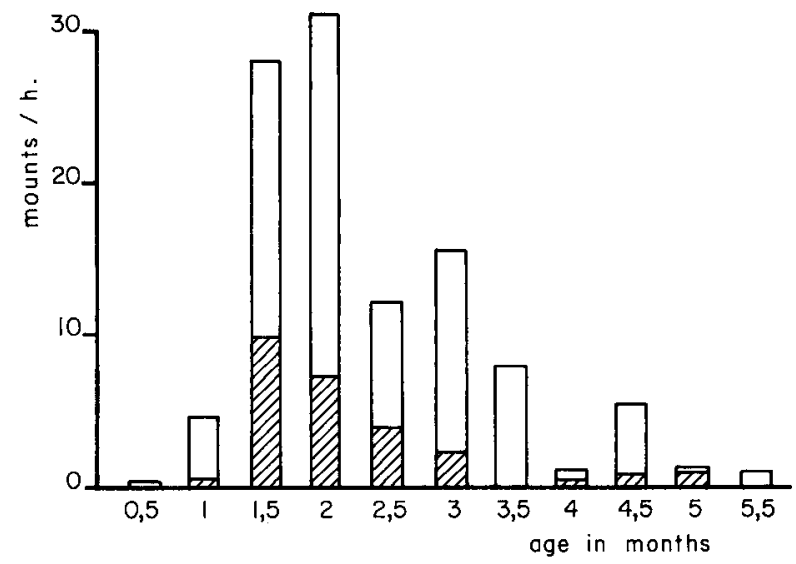

FIG. 1. - Evolution of sex play in the young pigs. Open bars : boars; Striped bars : sows.

2) Castrated boars. - Castration was carried out at selected ages to determine if there was a relationship between the pattern of androgen secretion and behavioural reactions. The mean frequency of mounting observed during the development of young boars was influenced by age at castration $(P<0.025$; fig. 2) ; only those castrated at birth showed a significantly lower activity level than intact boars. The effect of castration at birth was evidenced mainly by the reduction of the frequency of sex play which became apparent during the second neonatal month, a period when this play reached a maximum in the intact piglets. This maximum was not modified by castration at 30 days of age. In this case, the effect only appeared during the third month $(P<0.01)$. Finally, when castration was carried out at 2 months of age, there was no influence on the pattern of sex play intensity. To summarize, castration at birth eliminated sex play; at 1 month, the effects were still evident, and beyond 2 months, castration had no effect on sex play. 

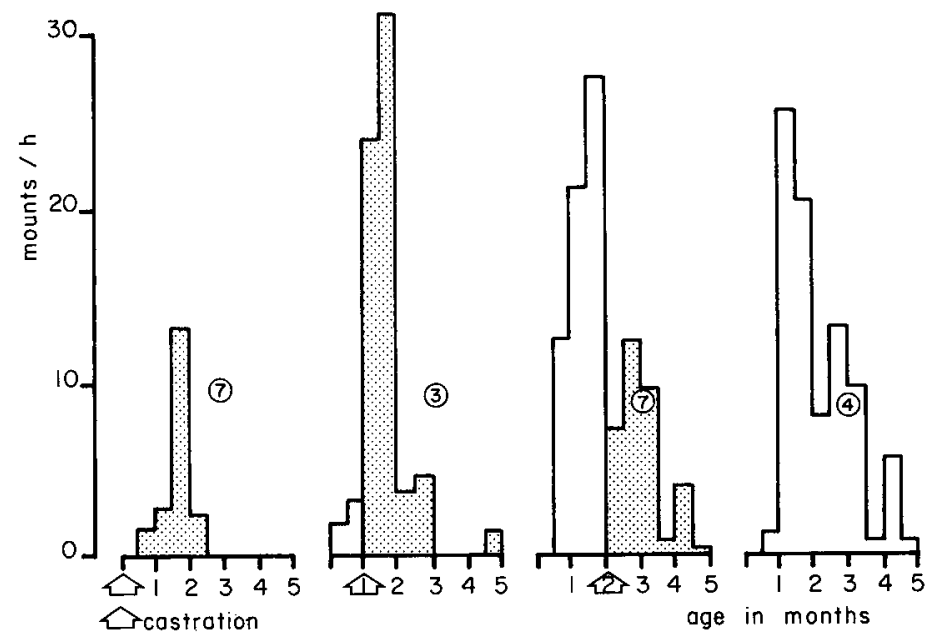

FIG. 2. - Evolution of sex play in young male pigs as a function of age at castration. Stipped bars : observations after castration. The numbers in the circles indicate the number of animals per group.

\section{B. Adult female sexual behaviour.}

At least a part of the boars castrated at various ages presented a female-type behaviour after receiving an oestrogen injection. Three days after an intramuscular injection of oestradiol benzoate $(1 \mathrm{mg} /$ animal), they displayed a characteristic immobilization reaction when an intact boar was present. By its nature, conditions of appearance and length, this response was analogous to that of a sow in oestrus. The female reaction could be elicited for $3.3 \pm 0.5$ days in boars castrated before 60 days.

The capacity to display this female-type reaction differed according to the age at which the boars were castrated. The percentage of animals reacting was significantly lower $(P<0.01)$ in those castrated after 120 days of age (fig. 3 ).

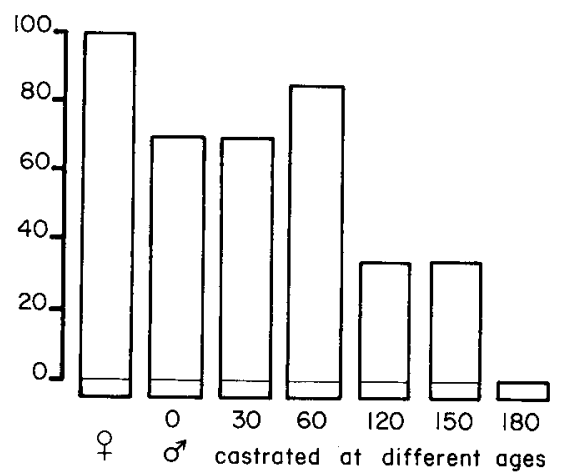

FIG. 3. - Percentage of female-like immobilization responses in boars after oestrogen treatment as a function of age at castration. 
Moreover, when castration was carried out at, or after, 60 days, the time during which female reactions appeared was reduced to $2 \pm 0.4$ days.

An intact boar presented for the first time to an untreated castrate made sexual approaches, ending by an attempt to mount. These attempts caused the castrate to run away. When the boar was presented again to the untreated castrate, these types of interaction disappeared. On the other hand, at the first trial after the castrate had been treated with oestrogen, the intact boar presented the whole range of sexual display: naso-nasal and naso-anal contact, pushing the head against the flank and mounting, to which the castrate reacted by an immobilization reaction analogous to that of a receptive sow. The time pattern of these displays was analogous to that of heterosexual interactions. The reaction times, for instance, were analogous to those recorded when the same boar was presented to a sow in oestrus (table 1).

TABLE 1

Latency to the first mount in a sexual behaviour test of an experimental pig with an intact boar.

\begin{tabular}{lcc}
\hline Experimental pig & Number of tests & Mean latency \\
\hline Sow in oestrus & 22 & $78 \pm 12.6$ \\
Oestrogen-treated castrated boar & 28 & $108 \pm 9.0$ \\
\hline
\end{tabular}

\section{Discussion and conclusion.}

Our results confirm those of Ford (1982) and indicate that the loss of the capacity of female-type response is progressive and late in boars. In $35 \%$ of cases, those castrated at 150 days of age showed a typical female behaviour after the injection of $1 \mathrm{mg}$ of oestradiol benzoate, whereas physiological puberty is practically attained at this age in Large-White boars.

We hypothesized that piglet sex play might be related with the sexualization process. We could not determine the motivation or finality of this activity, and it was much more frequent in young boars than in young sows. The pattern of sex play intensity was very characteristic, having a maximal frequency during the second neonatal month. This phenomenon is analogous to that described in lambs by Orgeur (1982). In this species, the capacities for female sexual responses have not been tested in rams and the effects of castration on sexual play have not been investigated. However, it is remarkable that the pattern of sex play is similar in two different species which have a comparable physiological development. Maximal mounting frequency occurred during a period when the overall plasma testosterone declined and was low compared to that of the first neonatal hours or days (Meusy-Dessolle, 1976). 
Plasma oestrogens in boars are high, changing concurrently with testosterone during postnatal development (Ford, 1983), and could also account for both the triggering of sexual behaviour reactions and brain sexualization.

The castration experiments show that this sex play is affected by the presence of testes. It is thus logical to consider it as endocrine-independent. This is the first behavioural response associated with early testicular secretion. However, this dependence is not parallel to the process leading to the sexualisation of the nervous mechanisms of sexual behaviour.

Neonatal castration eliminates most of the sex play and, at the same time, permits the adult to act (after oestradiol injection and in the presence of a boar) by showing the immobilization reaction typical of a receptive sow.

On the contrary, castration at 60 days does not markedly change the appearence and progression of the sex play characterizing boars; however, in these conditions, young boars present a female-type response. The effects of castration on sex play, on the one hand, and on the capacity to present an adult female-type of behavioural reaction on the other, are thus independent. When the young boar is castrated at 2 months of age, sex play develops normally, whereas the mechanisms of sexual behaviour are not differentiated. Thus, the question remains as to the mechanisms and physiological significance of this sex play which is partly hormone-dependent. The progression and slowness of the process of sexualization of the nervous mechanism in pigs, the variability of its dynamics and its independence from the mechanisms controlling gonadotropic secretion seem to make this species an ideal model for studying the sexual specificity of neuroendocrine and behavioural reactions.

Reçu en décembre 1983. Accepté en avril 1984.

Acknowledgements. - We wish to thank Messrs. Despres and Gautier for animal care, $\mathrm{Mr}$ J.-M. Faure for developing the data processing programs and J. Pelletier for critical reading of the paper.

Résumé. Jeu sexuel et sexualisation comportementale chez le Porc.

Le porcelet présente les diverses phases motrice et posturales du comportement copulatoire de l'adulte. Ce jeu sexuel, beaucoup plus fréquent chez le mâle que chez la femelle, atteint une intensité maximale au cours du second mois de la vie.

La castration du jeune mâle à la naissance (7 animaux) supprime la phase du jeu sexuel intense. Par contre, celle-ci n'est que peu modifiée lorsque la castration est réalisée à 30 jours ( 3 animaux) et est inchangée à 60 jours (7 animaux).

A l'âge adulte, les verrats castrés à la naissance, à 30 ou 60 jours présentent, au même taux que les femelles, une réaction d'immobilité caractéristique de la réceptivité sexuelle en réponse à une injection intramusculaire de $1 \mathrm{mg}$ de Benzoate d'OEstradiol. Lorsque la castration est faite à 120 ou à 150 jours (4 animaux dans chaque cas), le taux de réponse femelle est abaissé à $35 \%$. II n'a pas été observé de réaction d'immobilisation de type femelle chez les 3 mâles castrés à 180 jours.

Ces résultats confirment que la sexualisation des processus nerveux en jeu dans la mise en œuvre du comportement sexuel est lente et progressive chez le porc mâle. Le jeu sexuel, bien qu'hormonodépendant ne paraît pas lié à ce processus de sexualisation. 


\section{Références}

FORD J.-J., 1982. Testicular control of defeminization in male pigs. Biol. Reprod., 27, 425-430.

FORD J.-J., 1983. Serum estrogen concentrations during post-natal development in male pigs. Proc. Soc. exp. Biol. Med., 174, 160-174.

FORD J. J., SCHANBACHER B. D., 1977. Luteinizing hormone secretion and female lordosis behaviour in male pigs. Endrocrinology, 100, 1033-1038.

MEUSY-DELSOLLE N., 1976. Evolution du taux de testostérone plasmatique chez le porc mâle de la naissance à l'âge adulte. Journées Rech. Porcine en France, 7, 165-170.

ORGEUR P., 1982. Ontogenèse du comportement sexuel male chez les ovins domestiques (Ovis aries L.). Effet de I'environnement social. Thèse Doct. Univ. ès Sci. Nat., Univ. Tours, $92 \mathrm{pp}$.

SIGNORET J.-P., 1972. Contribution à l'étude des mécanismes éthologiques et endocriniens du comportement sexuel de la truie (Sus scrofa L.). Thèse Doct. Etat ès Sci. Nat., Université de Paris VI, $180 \mathrm{pp}$.

WHALEN R. E., EDWARDS D. A., 1967. Hormonal determinants of the development of masculine and feminine behaviour in male and female rats. Anat. Rec., 157, 173-180. 